\title{
The rock art of Ingaanjalwurr, western Arnhem Land, Australia
}

\author{
Sally K. May, Denis Shine, Duncan Wright, Tim Denham, \\ Paul S.C. Taçon, Melissa Marshall, Inés Domingo Sanz, \\ Faye Prideaux and Sean Paul Stephens
}

\section{Introduction}

The painted and beeswax rock art of Ingaanjalwurr rockshelter in western Arnhem Land is a unique assemblage of art within an unassuming rockshelter. By combining a variety of approaches and methods to the study of Ingaanjalwurr, we were able to draw together an important archaeological context for inferring the antiquity of the painted rock art, as well as direct dates for the age of beeswax art. This chapter provides an overview of the rock art at Ingaanjalwurr, ethnographic information regarding the use and production of art at the site, archaeological information relevant to understanding the antiquity and context of painted rock art, and the results of direct dating of beeswax art.

It has been argued that rock art on the northwestern Arnhem Land plateau provides evidence for 'outbursts of art production' as opposed to 'a steady, constant rate over time' (Taçon 1993:113). Taçon (1993) reached this conclusion by examining the chronology of different styles within his study areas, and counting the number of images representing each style. He suggests that two of the most significant such outbursts are represented by Dynamic Figure art and the later Freshwater, Recent X-ray art (Taçon 1989, 1993), with relatively little rock art production between these two periods (Taçon 1993:113). A similar conclusion is reached by Gunn et al. (2012:61) for Nawarla Gabarnmang in Jawoyn Country, western Arnhem Land, arguing that a large quantity of rock art was produced in that site within the past c. 350 years (see also Chapters 11 and 12; David et al. 2011:76; Gunn et al. 2012:61). The Ingaanjalwurr site provided an opportunity to further explore such 'outbursts of art production' for western Arnhem Land.

\section{Ingaanjalwurr rockshelter}

Ingaanjalwurr is a rockshelter located in Manilikarr Country, western Arnhem Land. It is situated at the base of an escarpment that overlooks Red Lily Lagoon (Urrmarning) (Figure 3.1). The escarpment runs broadly east-west, parallel to the main Jabiru-Gunbalanya (Oenpelli) road, and reaches a maximum elevation of $75 \mathrm{~m}$ above sea level directly behind Ingaanjalwurr. The rockshelter is c. $9 \mathrm{~km}$ southwest of Gunbalanya, with Ingaanjalwurr being the Urningangk 
name (original language of the Nayinggul family and Manilakarr clan) for the site provided by senior Traditional Owner Nakodjok (who passed away in 2012; in respect of his family's wishes, we refer to him only by his skin name).

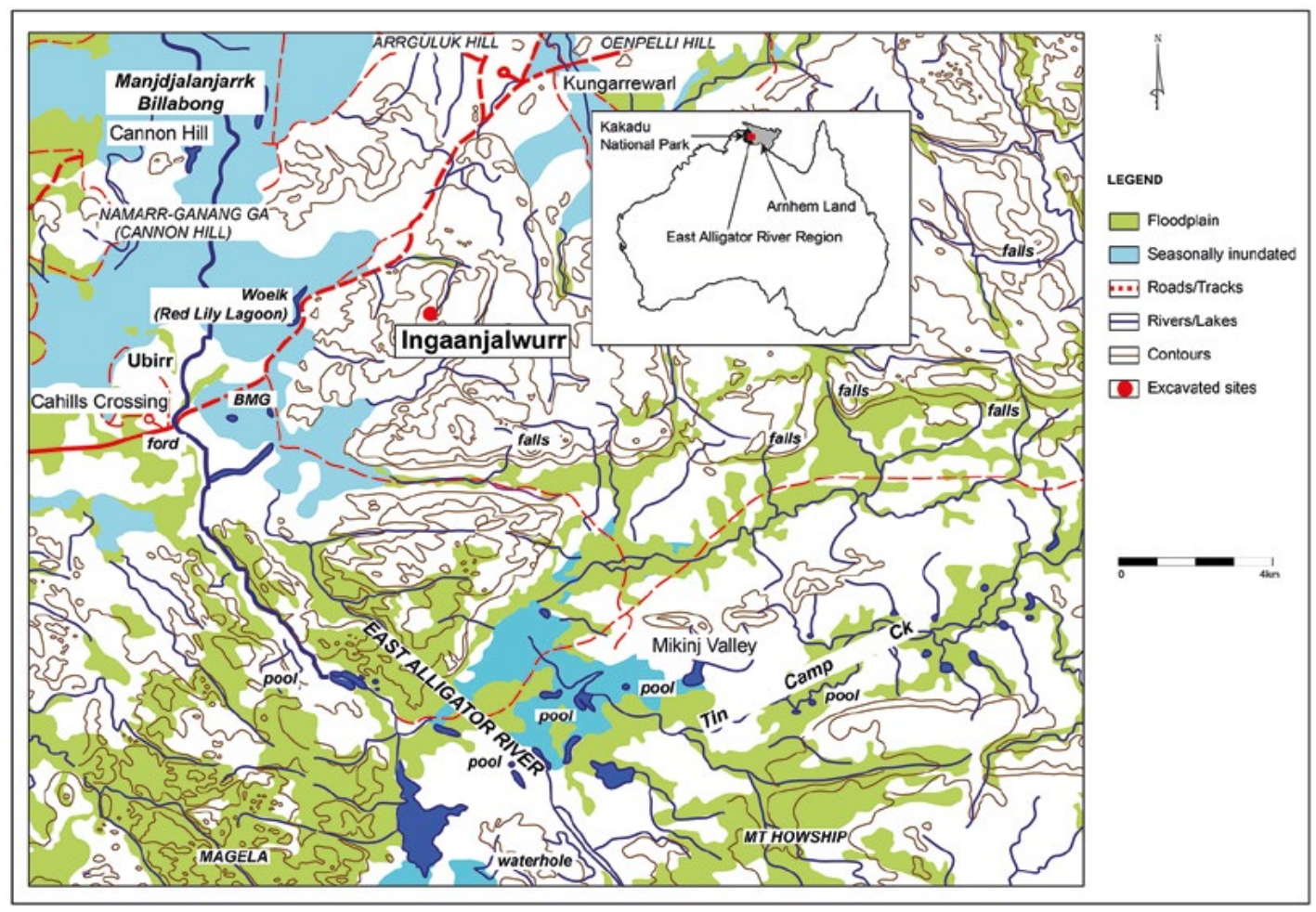

Figure 3.1 Location of Ingaanjalwurr and other key sites mentioned in this chapter, in relation to topography.

Source: Map by Duncan Wright.

The name Urrmarning derives from a purple lily (Nymphaeaceae spp.) that is common within Red Lily Lagoon. It applies to a rockshelter (Urrmarning rockshelter), the lagoon and much of the surrounding landscape (Figure 3.2). The English name Red Lily Lagoon is commonly used today, and has been in use since c. 1900 when the buffalo hunter Paddy Cahill was working in the area (Mulvaney 2004). The Red Lily vicinity also contains a rockshelter complex named Minjnyimirnjdawabu, which was partially recorded as Inagurdurwil during the AmericanAustralian Scientific Expedition to Arnhem Land (the 'Mountford Expedition') in 1948 (Mountford 1956). The rock art of both Minjnyimirnjdawabu and Urrmarning have been partially recorded in more recent times by Robert Gunn (1992).

The Ingaanjalwurr site itself is $10.5 \mathrm{~m}$ wide, $3.5 \mathrm{~m}$ deep and has a maximum height of $1.6 \mathrm{~m}$. It is located under a c. $15 \mathrm{~m}$ wide sandstone boulder that possesses a wall inclined at an angle of c. $45^{\circ}$ on its northern side (Figure 3.3). A semi-circular ring of roof-fall surrounds the shelter floor, providing some protection to the accumulated deposits and rock art. While no disturbance of the floor deposits from feral animals or macropods is apparent, two dormant termite mounds were observed at the dripline. A number of small trees are positioned at the northern limit of the overhang. Surface deposits of charcoal, as well as the painted and beeswax art, indicated prior human use of the rockshelter. The rock art and surface charcoal are concentrated in two locations where rockfall seemed to have provided greatest head room. 


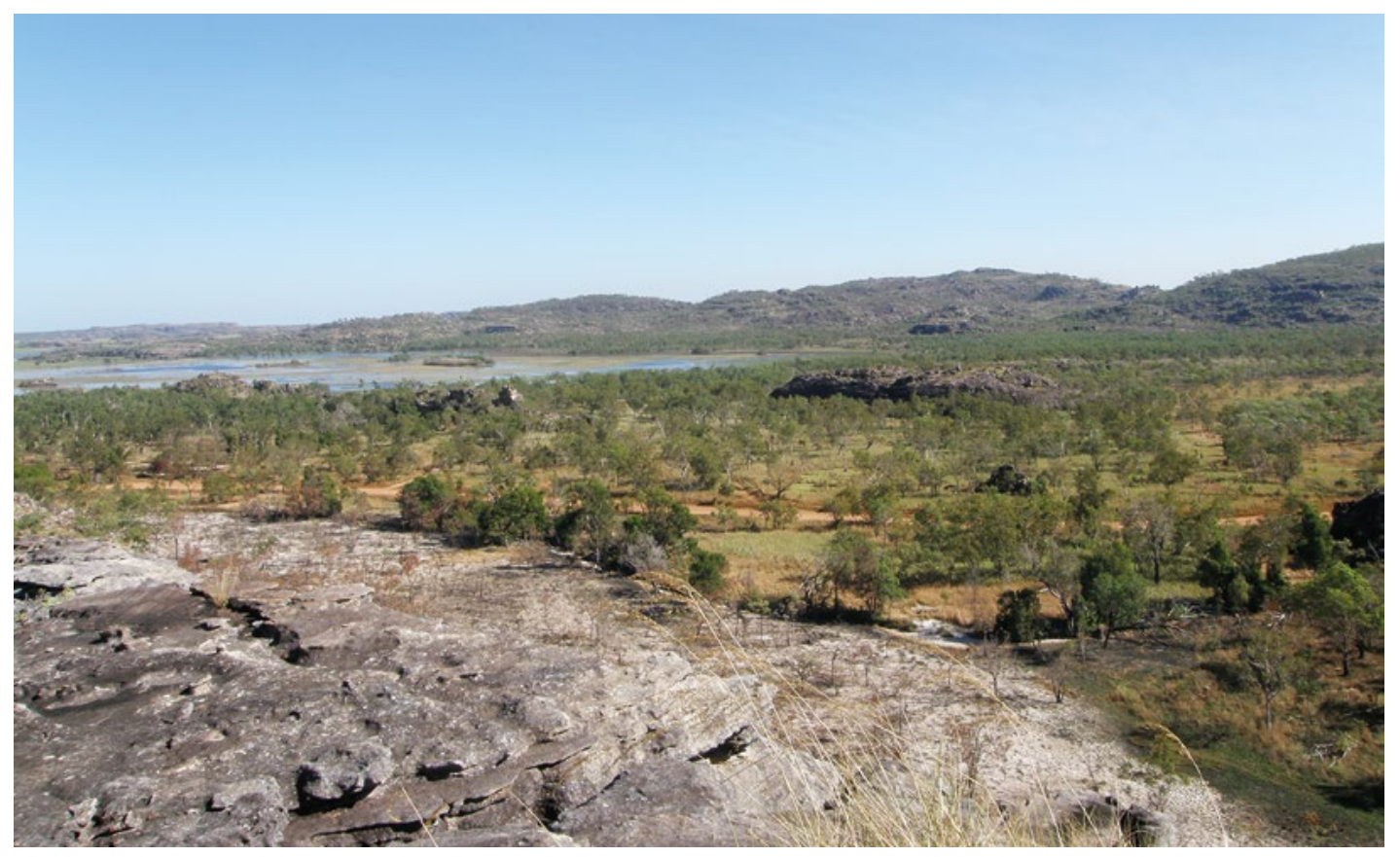

Figure 3.2 View towards Red Lily Lagoon from the escarpment at the rear of Ingaanjalwurr. Source: Photograph by Duncan Wright.

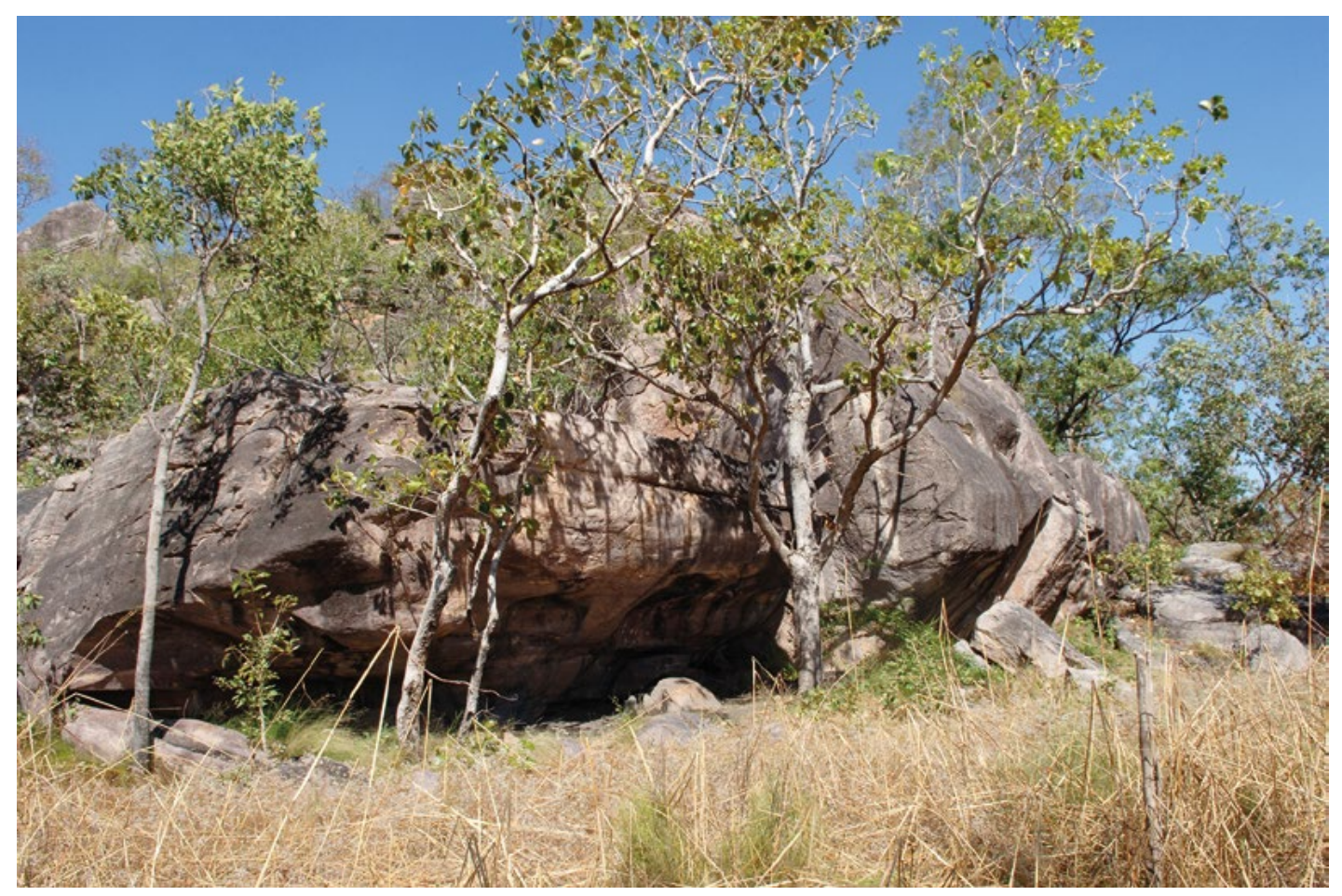

Figure 3.3 Ingaanjalwurr rockshelter from the north.

Source: Photograph by Sally K. May. 


\section{Rock art of Ingaanjalwurr}

Western Arnhem Land, and in particular Kakadu National Park within it, are widely acknowledged as one of the world's great rock art provinces. Internationally recognised through UNESCO World Heritage Listing for its rock art heritage, this region has one of Australia's largest concentrations of rock art sites (Chaloupka 1993; May and Taçon 2014:4235). The vast majority of rock art in this region is painted or stencilled, with fewer engravings, prints and beeswax figures. Ingaanjalwurr has a high density of beeswax art ( 45 examples) compared to the more typical painted art (76 examples).

Beeswax rock art concerns the application of native Australian beeswax onto rock surfaces in what Brandl (1968:19) describes as an 'assumed deliberate design'. Such designs can be made by forming pellets, strips and sheets from the prepared wax. The use of the word 'beeswax' for this type of rock art is not as straightforward as it first appears. The 'beeswax' used for rock art is a resinous compound. There are rare examples of rock art made from other resinous substances including gabbai, made from the roots of the ironwood tree (Erythrophleum chlorostachys), and another resin called kalapartaman found in central Arnhem Land (Chaloupka 1993:161; Taçon and Garde 2000:71). Throughout this chapter, the term 'beeswax' (sugarbag wax such as that found at Ingaanjalwurr) is used as a common name for the substance left when the honey has been extracted from a clump of sugarbag (the nest-building material of the Australian native stingless bee). The majority of beeswax art is found in northern Australia, specifically western Arnhem Land and the Kimberley, with a few scattered examples in northern Queensland.

The first researcher to publish specifically on beeswax art was Brandl (1968). Brandl (1968:1929; 1973:177) recorded nearly 30 images from eight rock art sites in western Arnhem Land and recognised the potential for directly radiocarbon dating beeswax art. Following Brandl's work, there was a break in detailed published research that lasted nearly 20 years and ended with the commencement of the 'Beeswax Art Project' in the 1990s (Nelson 2000; Nelson et al. 2000; Taçon and Garde 2000). Other researchers (e.g. Bednarik 2001; Chaloupka 1993:158-161; Gunn and Whear 2008; Gunn et al. 2012; Morwood et al. 2010; Taçon et al. 2003, 2004, 2010; Walsh 1988; Welch 1995) have used beeswax art to develop site chronologies and as part of general rock art studies. Most beeswax art dates to within the past 1500 years (e.g. see Gunn and Whear 2008; Morwood et al. 2010; Taçon and Garde 2000:74), although one example has been dated to c. 4000 years ago (Nelson et al. 1995:152; Watchman and Jones 2002).

Previous ethnographic research offers interpretations into the social role of beeswax art in Arnhem Land. Brandl (1968:28) suggested that retouched beeswax art may have been indicative of increased ritual use of a site. Other researchers have noted that single pellets or irregular lumps of beeswax were stuck to rock for good luck when playing cards in central Arnhem Land and as a tick removal procedure in western Arnhem Land (Chaloupka 1993:158; Taçon and Garde 2000:74). It has also been argued that by forming double rows of dots or depicting the SpiritBeing Narmarnde, it was possible to make a rockshelter habitable for the next season (Chaloupka 1993:158; Taçon and Garde 2000:74).

Rock art recording took place at Ingaanjalwurr in 2006 (beeswax art) and again in 2011 (paintings), with the latter occurring at the same time as the archaeological excavations.

\section{Rock paintings}

A total of 76 painted images were identified at Ingaanjalwurr, a considerable number given the small size of the rockshelter and relative exposure of the panels to direct sunlight and rain in the wet season. Two clearly distinct groups of paintings were recorded - red images (including all anthropomorphic figures, e.g. Figure 3.4) and white-infilled images usually with red outlining (Figure 3.5). While often in poor states of conservation, and superimpositions at times partly obscure underlying images, Table 3.1 presents a general list of motif shapes. 
Table 3.1 General interpretation of the painted art at Ingaanjalwurr rockshelter.

\begin{tabular}{|l|r|}
\hline Interpretation & Number \\
\hline Human-like figure & 33 \\
\hline Unidentified & 15 \\
\hline Line/s & 11 \\
\hline Geometric & 9 \\
\hline Fish & 4 \\
\hline Material culture (spear) & 2 \\
\hline Snake & 2 \\
\hline Total & 76 \\
\hline
\end{tabular}

Source: Authors' data.

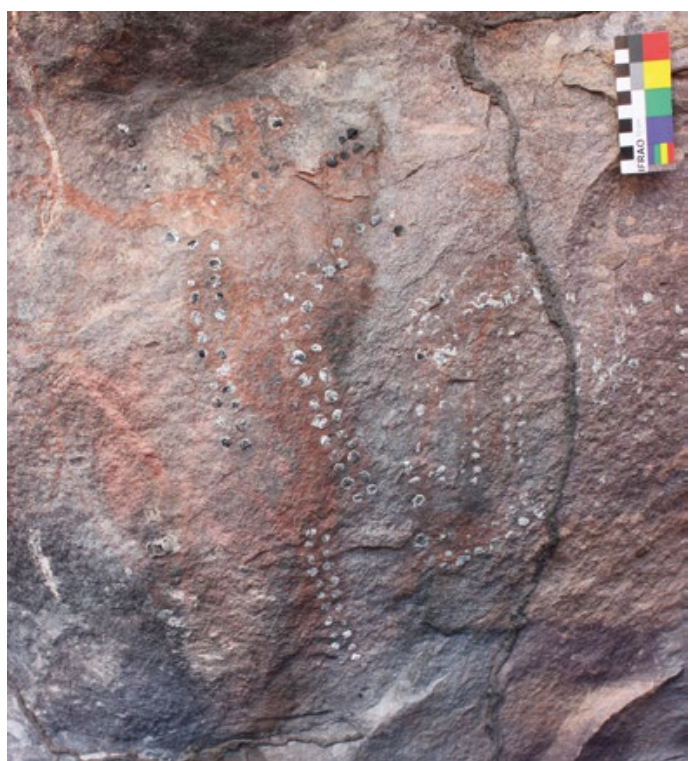

Figure 3.4 An example of the red painted anthropomorphs of Ingaanjalwurr.

Source: Photograph by Melissa Marshall.

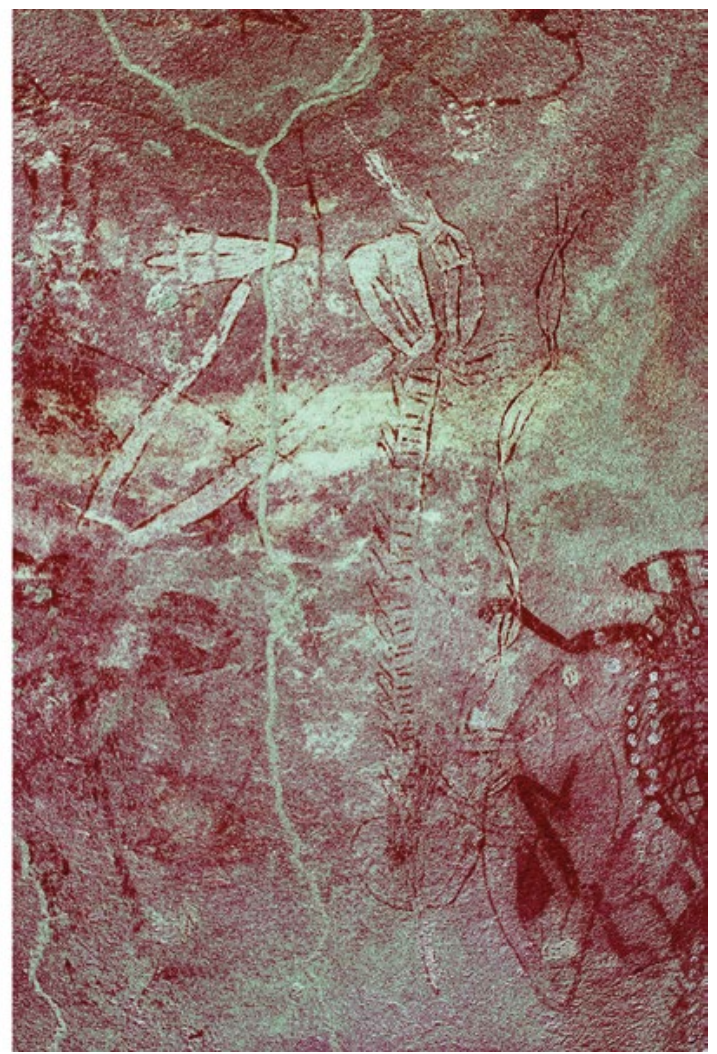

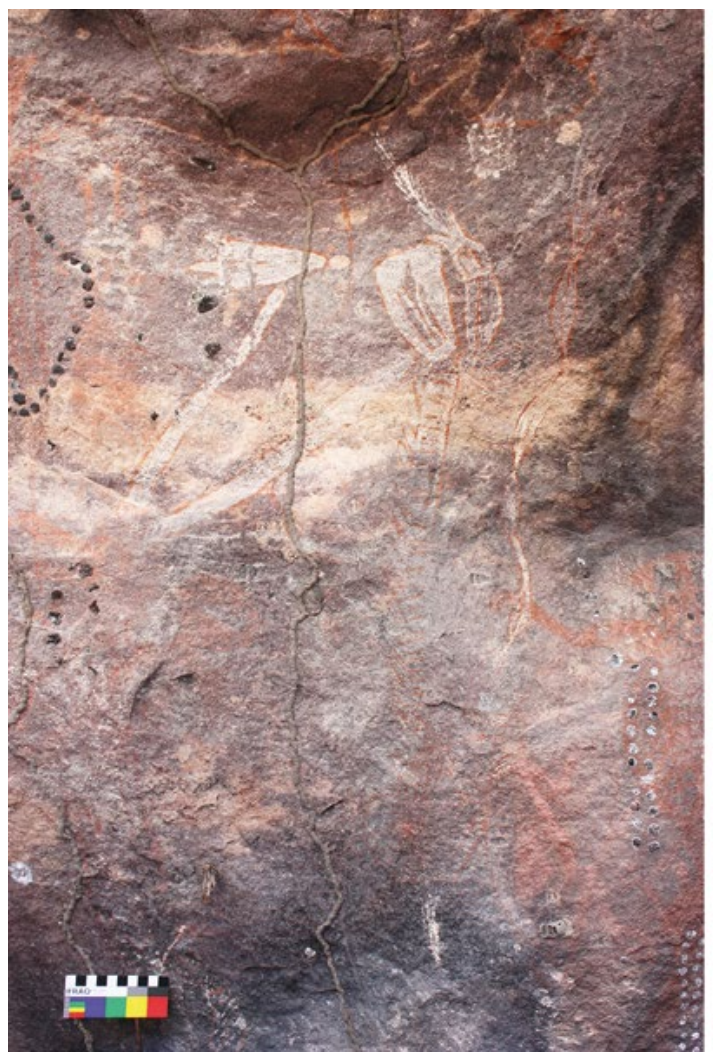

Figure 3.5 A white-infilled red-outlined painting (sorcery figure) from Ingaanjalwurr.

The image on the right was digitally enhanced using Dstretch YRD colourspace.

Source: Photograph by Melissa Marshall. 
Anthropomorphs dominate the painted art, followed by unidentified forms, simple single or double line paintings and geometric figures. While fish and snakes (including one doubleheaded snake) occur, they do so in small numbers (Table 3.1). Fourteen of the anthropomorphs display aspects of so-called 'sorcery' art previously documented from across much of western Arnhem Land, such as distorted limbs and/or spears in their joints and appendages (see Figure 3.5). Sorcery images are common throughout the East Alligator River region and elsewhere in Arnhem Land (Chaloupka 1993:207-211). On nearby Injalak Hill, one sorcery painting was ethnographically documented to have been produced to bring pain to the depicted individual, and other sorcery figures were painted to represent evil spirits such as Namorrodoh (May 2006; Taylor 1996; W. Nawirridj, pers. comm. to Sally K. May 2010).

Another four of the human-like rock art figures appear to have Yawk Yawk (female water spirit/ mermaid) tails instead of legs. Yawk Yawk is the Kunwinjku language term used for young women, but it is also used for special female water spirits that have fish tails. Sometimes they are described as mermaids that are said to live in water in special places in western Arnhem Land. They are considered minor regional spirits (alongside Mimi, Namorrodoh and other types of Spirit-Beings) that are still painted today by artists in western Arnhem Land (May 2006; Taylor 1996:88).

The painted art at Ingaanjalwurr is dominated by depictions of human figures and minor Spirit-Beings that are still widely known today in western Arnhem Land. This is unusual for painted shelters of this region, where the recent rock art is more often dominated by depictions of local food sources such as fish (Taçon 1988, 1989). On stylistic grounds, painted images at Ingaanjalwurr correspond to the later Estuarine Period and early Freshwater Period, which are thought to date to the past 3000 years or so (Chaloupka 1993:153-189).

\section{Beeswax rock art}

Forty-five beeswax images have been recorded at Ingaanjalwurr rockshelter. These are in varying states of preservation. The beeswax images appear to follow contours of the rock surface, and cluster in small groups of stylistically similar images. Figure 3.6 and Table 3.2 illustrate and describe each of the recorded beeswax images.

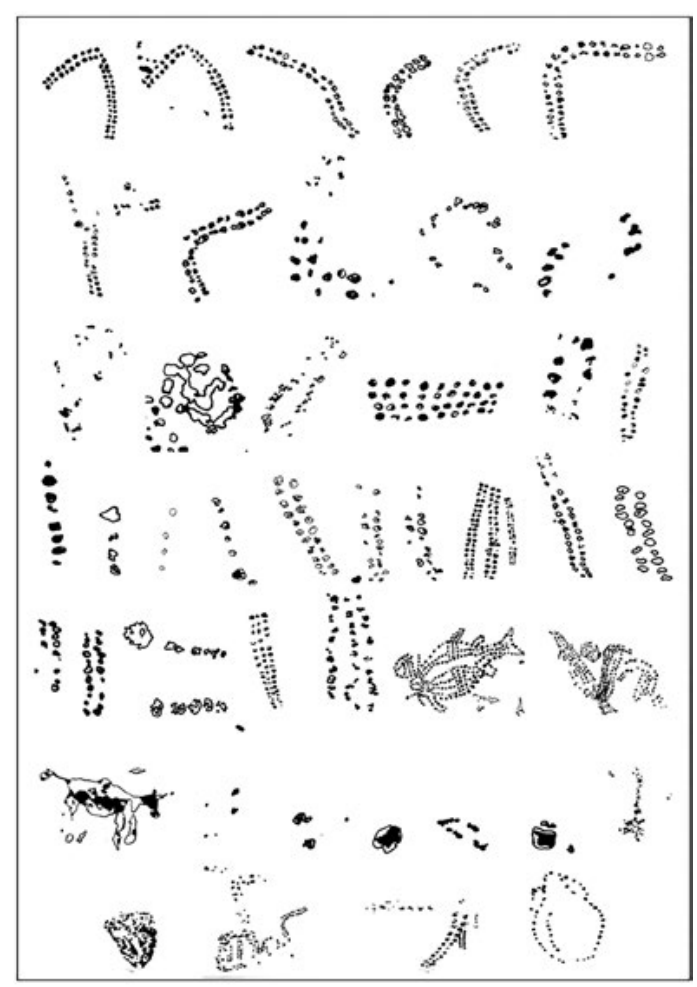

Figure 3.6 Digital tracings of photographed beeswax images from Ingaanjalwurr (images are at different scales to each other). Darker colouring indicates greater thickness of surviving beeswax, with lighter areas signalling only staining remaining on the rock surface.

Source: Digital tracings by Faye Prideaux. 
Table 3.2 General classification and description of beeswax images from Ingaanjalwurr rockshelter.

\begin{tabular}{|c|c|c|}
\hline Classification & Description & Number \\
\hline \multicolumn{3}{|l|}{ Geometric } \\
\hline & Circular, outlined & 5 \\
\hline & Double rows, vertical & 4 \\
\hline & Double rows, horizontal & 4 \\
\hline & Arched double row, facing left & 3 \\
\hline & Arched double row, facing right & 3 \\
\hline & Single rows, vertical & 2 \\
\hline & Triple rows, vertical & 2 \\
\hline & Rectangles, in-filled & 2 \\
\hline & Rectangles, outlined & 1 \\
\hline & S-shape & 1 \\
\hline \multicolumn{3}{|l|}{ Figurative } \\
\hline & Barramundi & 1 \\
\hline & Unidentified fish & 1 \\
\hline & Unidentified fish or turtle & 1 \\
\hline & Horse or cow & 1 \\
\hline \multicolumn{3}{|l|}{ Abstract } \\
\hline & Unknown & 4 \\
\hline & Combination geometric shapes & 3 \\
\hline \multicolumn{3}{|l|}{ Pellets } \\
\hline & Single pellets & 4 \\
\hline & More than one pellet & 3 \\
\hline Total & & 45 \\
\hline
\end{tabular}

Source: Authors' data.

As can be seen in Figure 3.6, most (93 per cent) of the beeswax images at Ingaanjalwurr consist of applied dots. Only one image was created using the strips of beeswax, and two images (including a quadruped) were constructed by applying sheets of beeswax.

The beeswax images are mainly geometric in design, with circular and row designs being most common (Table 3.2). Of the row designs, double rows and arched double rows predominate (see Figure 3.6). Only four figurative images were clearly identified: a barramundi (Figure 3.7), an unidentified fish, an unidentified fish or turtle and a horse or cow (Figure 3.8). The barramundi is depicted with its head broken, said to assist with carrying the fish back to camp (Thompson Yulidjirri, pers. comm. to Sally K. May 2005). This manner of depiction is common in painted art of this region (Taçon 1989) (Figure 3.9). The beeswax fish are the only examples yet published of such imagery from western Arnhem Land.

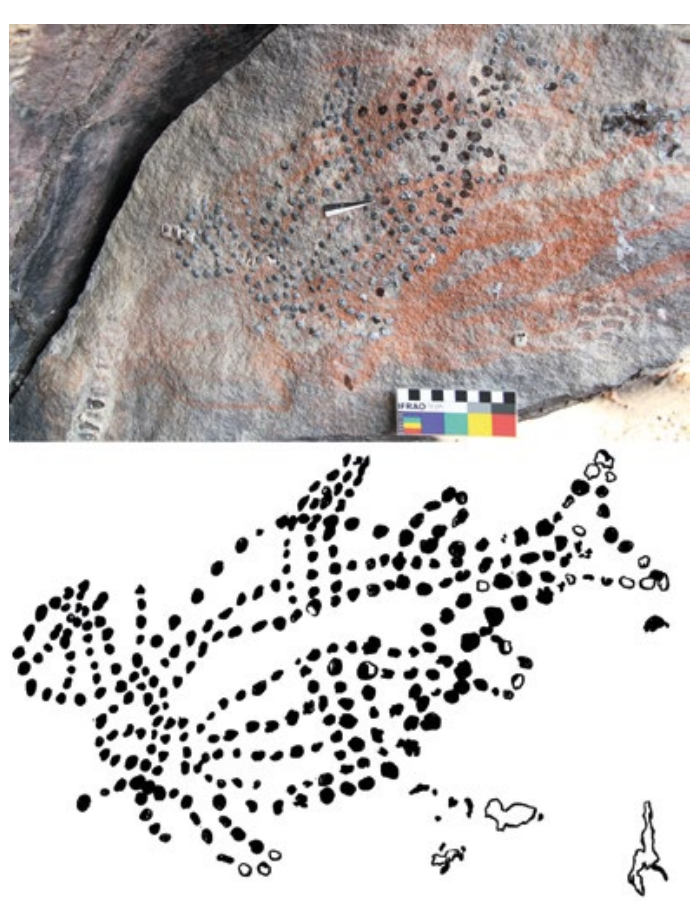

Figure 3.7 Beeswax image of a fish, with arrow indicating location from which Sample 1 was taken.

Source: Photograph by Paul S.C. Taçon. 

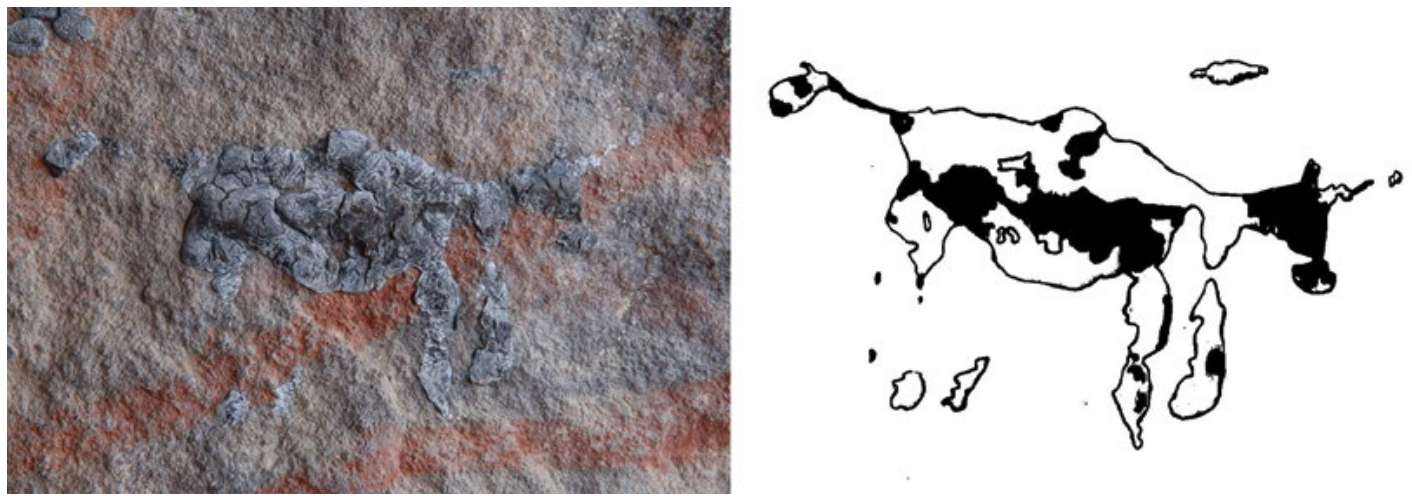

Figure 3.8 Unidentified beeswax quadruped from Ingaanjalwurr.

Source: Photograph by Sally K. May.

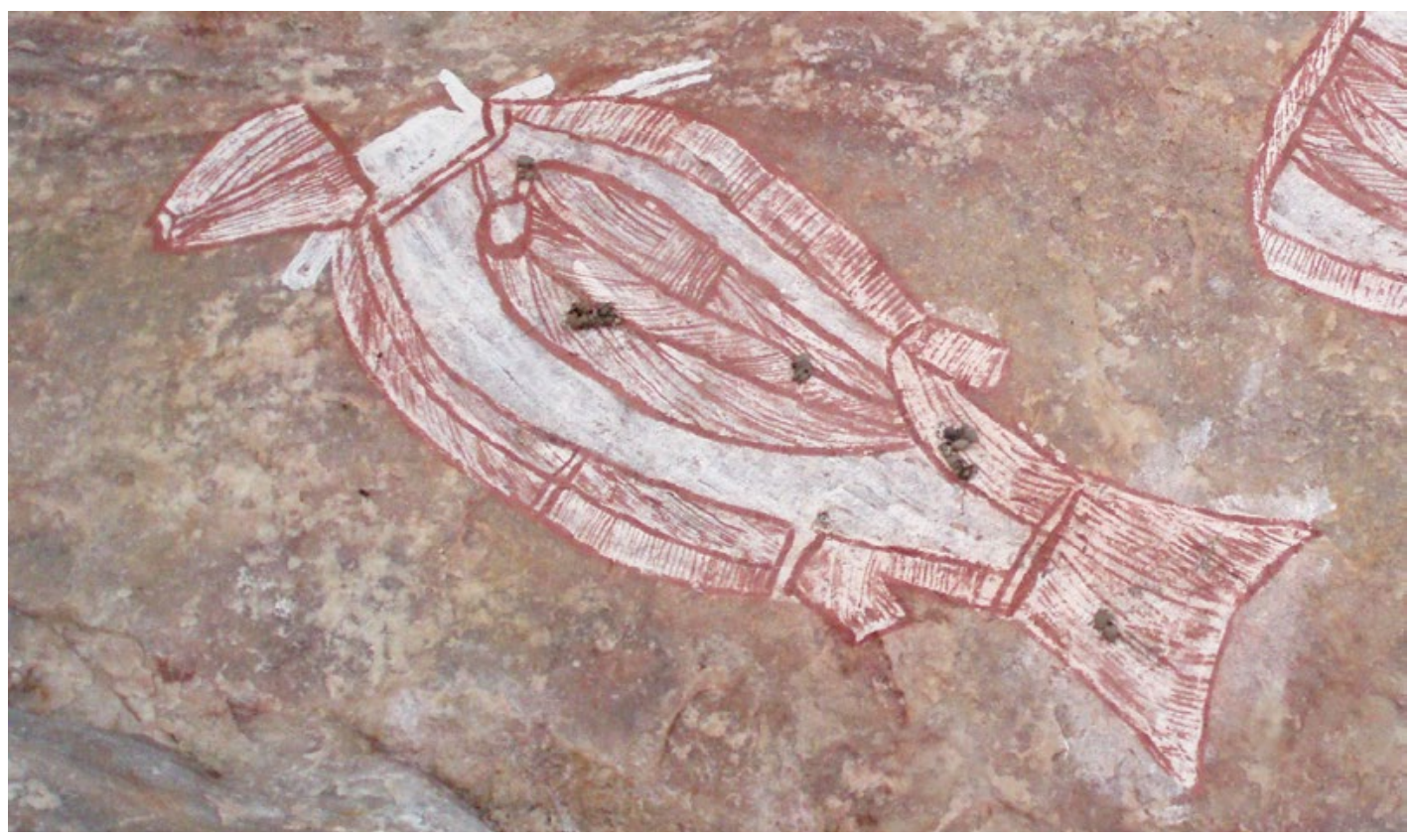

Figure 3.9 Painting of a fish with head broken to assist with carrying, Injalak Hill.

Source: Photograph by Sally K. May.

The quadruped is clearly a European-contact period figure, most likely depicting a horse. Rock art produced during the contact period is widely documented for western Arnhem Land (e.g. see Chaloupka 1979, 1993; Gunn et al. 2012; May et al. 2010; Taçon et al. 2010). The depiction of horses is rare but not unique in this region. A remarkable example of a painted image of a horse was recently documented at Nawarla Gabarnmang in Jawoyn Country (Gunn et al. 2012:60; Chapter 12), and may date from Leichhardt's 1845 expedition across the region. The Ingaanjalwurr depiction of a horse or cow in beeswax is unique, however, as no other such depictions are known.

Most of the beeswax art at Ingaanjalwurr is in a poor state of preservation, with pellets exfoliating from the rockshelter walls. Despite the detachment of pellets from the wall, none were recovered in the excavations. Many of the geometric images are badly deteriorated, with termite tracks observed over several of the beeswax designs. Numerous images using dots have almost no beeswax remaining and remain identifiable only as stains or 'shadows' on the rock surface. This degradation made identification of several of the images difficult. 


\section{Direct radiocarbon dating of beeswax art}

To ascertain the antiquity of beeswax art, pellets from two images were collected for accelerator mass spectrometry (AMS) radiocarbon dating:

- Sample 1: A beeswax figure of a fish (Figures 3.7). This fish image is superimposed over a red painting of a human-like figure and, as such, provides a minimum age for that painting.

- Sample 2: A single line of beeswax pellets (Figure 3.10). This beeswax linework is superimposed over a red painted sorcery figure.

The resultant AMS dates on these beeswax pellets are both in good chronological agreement, suggesting they were both made sometime within the period 8-275 cal BP, and most likely sometime after $150 \mathrm{cal} \mathrm{BP}$ (Table 3.3). The similarity of the two radiocarbon dates for the two beeswax images suggests that these two types of figurative and geometric forms are broadly contemporaneous. The dating of the beeswax art also provides minimum ages for the paintings that underlie them. At Ingaanjalwurr, beeswax images frequently overlie the painted art in patterns of superimposition, but never the reverse.

Table 3.3 Radiocarbon dates from Ingaanjalwurr beeswax figures.

\begin{tabular}{|l|c|c|c|c|}
\hline Sample & Laboratory code & $\delta C 13$ & Radiocarbon age (BP) & Calibrated age (95.4\% Probability) (cal BP) \\
\hline 1 & ANU-31021 & $-22.9 \pm 0.7$ & $130 \pm 30$ & $275-172(37.9 \%)$ \\
& & & & $152-56(42.5 \%)$ \\
& & & & $45-8(15.0 \%)$ \\
\hline 1 (duplicate) & ANU-31023 & $-22.6 \pm 0.9$ & $120 \pm 30$ & $271-186(32.4 \%)$ \\
& & & & $176-174(0.4 \%)$ \\
& & & & $150-10(62.6 \%)$ \\
\hline 2 & ANU-31024 & $-24.9 \pm 0.2$ & $120 \pm 25$ & $270-186(31.3 \%)$ \\
& & & & $150-11(64.1 \%)$ \\
\hline
\end{tabular}

Calibration after 0xCal 4.1 (Bronk Ramsay 2009). Ingaanjalwurr lies at the southern boundary of the Inter-tropical Convergence Zone (ITCZ), an area that may be influenced by Northern Hemisphere air masses (Hogg et al. 2013; Hua et al. 2012). For this reason the calibrations were performed with the IntCal 09 dataset of Reimer et al. (2009).

Source: Authors' data.

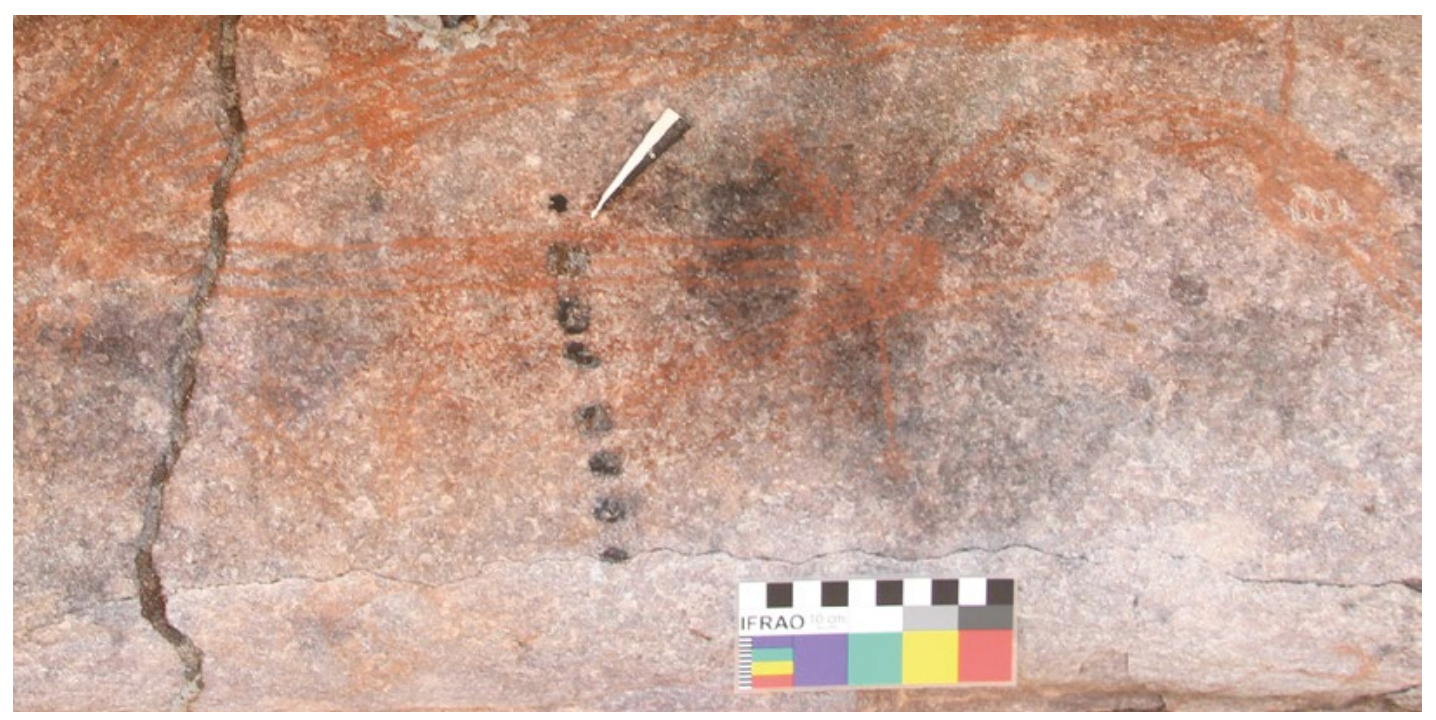

Figure 3.10 Single row of beeswax pellets, with arrow indicating location from which Sample 2 was taken.

Source: Photograph by Paul S.C. Taçon. 


\section{Archaeological excavations}

During June and July 2011, two $1 \times 1 \mathrm{~m}$ squares were excavated at Ingaanjalwurr (Squares 1 and 2). These were designed to provide information regarding the settlement history of the site and to explore relationships between sub-surface archaeology and the various rock art traditions evident on the rock walls (see Shine 2014 for detailed information on the excavation methods and results). Square 1 was positioned within the rockshelter's dripline in proximity to surface charcoal, the main concentration of rock art and smoke staining on the ceiling. The square was excavated in 34 excavation units (XUs) to a maximum depth of $68 \mathrm{~cm}$ below ground, although rockfall significantly reduced the excavation area below XU2. Square 2 was excavated just outside the dripline, c. $4.1 \mathrm{~m}$ northwest of Square 1 and beyond apparent surface rockfall. Square 2 was excavated in $40 \mathrm{XUs}$ and reached a maximum depth of $88 \mathrm{~cm}$, although here from XU6 down rockfall reduced the excavation area. Confined space forced the discontinuation of both excavations without reaching culturally sterile deposits.

The arbitrary XUs followed the observed strata during excavation. XUs averaged $2.0 \mathrm{~cm}$ in thickness in Square 1 and $2.2 \mathrm{~cm}$ in Square 2. All excavated sediments were dry-sieved through $2.1 \mathrm{~mm}$ mesh on-site, and then archaeologically floated through $250 \mu \mathrm{m}$ mesh at a dedicated field facility at Gunbalanya. The resultant floated and sieved materials were air-dried before being transported to Monash University (Clayton) for sorting and analysis. The provenance of artefacts observed in situ and large fragments of charcoal were plotted in three dimensions and individually bagged.

Both squares contained relatively homogenous brown sands, differentiated into three stratigraphic units based on variations in compaction and inclusions (primarily charcoal). Sediments were acidic, varying in $\mathrm{pH}$ from 3.0 to 3.4 in Square 1 and from 2.7 to 3.0 in Square 2. Minor biogenic disturbance from insects and roots was recorded in both squares.

Both squares exhibit good chronostratigraphic integrity (Table 3.4). In Square 1, the upper four dates span the period c. $500 \mathrm{cal}$ BP onwards; minor chronostratigraphic reversals are consistent with the 'old wood effect'. In general, in Square 1 the radiocarbon dates suggest relatively rapid sediment accumulation from XU26 onwards, from c. 500 cal BP to very recent times. A basal date from XU34 (Wk-33539) looks anomalously old (given the date from XU31) and potentially represents older, residual charcoal within mixed ancient and more recent sediments associated with the roof fall event. A broadly similar chronostratigraphic sequence occurs in Square 2, except for a younger-than-anticipated date from XU33 (Wk-33534) that is interpreted as intrusive, younger charcoal.

Archaeological excavations recovered a total of 617 stone artefacts; worked $(27.6 \mathrm{~g})$ and unworked (44.8 g) ochre, neither of which is natural to the site; three metal artefacts and one glass artefact from Square 2. Large quantities of charcoal were collected as sieved macrocharcoal pieces $(>2.1 \mathrm{~mm}$ : Square $1=1979 \mathrm{~g}$; Square $2=1607 \mathrm{~g})$, and also comprised the majority of retrieved flotation organics $(>250 \mu \mathrm{m}$ and $<2.1 \mathrm{~mm}$ : Square $1=2353 \mathrm{~g}$; Square $2=5231 \mathrm{~g}$ ). The vast majority of both the macro and floated charcoal from Ingaanjalwurr is considered to be associated with human occupation at the site, because peaks in macrocharcoal and flotation correspond to peaks in stone artefacts.

Ochre was recovered in both excavation squares: six pieces of unworked ochre $(1.0 \mathrm{~g})$ and two pieces of worked ochre $(8.3 \mathrm{~g})$ in Square 1, and 25 pieces of unworked ochre $(43.8 \mathrm{~g})$ and 11 pieces of worked ochre $(19.3 \mathrm{~g})$ in Square 2. Even allowing for its greater depth and greater amount of excavated sediment, Square 2 still contained significantly greater amounts of worked 
ochre than Square 1, with 85 per cent of the total number of worked ochre pieces coming from Square 2. This pattern of peak ochre deposition occurring outside the dripline may suggest spatial patterning of site use at Ingaanjalwurr.

Table 3.4 Radiocarbon dates on charcoal from Ingaanjalwurr (Squares 1 and 2).

\begin{tabular}{|c|c|c|c|c|c|c|}
\hline Laboratory code & $\mathrm{XU}$ & Square & $\begin{array}{l}\text { Depth below } \\
\text { ground }(\mathrm{cm})\end{array}$ & $\delta C 13$ & Radiocarbon age (BP) & $\begin{array}{c}\text { Calibrated age ( } 95.4 \% \\
\text { probability) (cal BP) }\end{array}$ \\
\hline Wk-33537 & 6 & 1 & 13 & $-27.4 \pm 0.2$ & $411 \pm 26$ & $\begin{array}{c}516-436(87.5 \%) \\
350-332(7.9 \%)\end{array}$ \\
\hline Wk-31823 & 11 & 1 & 23 & $-25.02 \pm 0.2$ & $233 \pm 25$ & $\begin{array}{c}310-270(51.4 \%) \\
187-149(35.1 \%) \\
127-(-) 4(8.9 \%) \\
\end{array}$ \\
\hline Wk-31822 & 14 & 1 & 28 & $-25.7 \pm 0.2$ & $296 \pm 25$ & $\begin{array}{c}455-444(1.9 \%) \\
439-348(65.8 \%) \\
334-296(27.7 \%) \\
\end{array}$ \\
\hline Wk-33538 & 26 & 1 & 53 & $-24.9 \pm 0.2$ & $301 \pm 25$ & $\begin{array}{l}456-348(70.5 \%) \\
334-300(24.9 \%) \\
\end{array}$ \\
\hline Wk-33589 & 31 & 1 & 62 & $-26.2 \pm 0.2$ & $1635 \pm 25$ & $\begin{array}{l}1606-1485(76.9 \%) \\
1469-1417(18.5 \%)\end{array}$ \\
\hline Wk-33539 & 34 & 1 & 68 & $-25.5 \pm 0.2$ & $8690 \pm 39$ & $\begin{array}{c}9762-9753(0.6 \%) \\
9744-9543(94.8 \%)\end{array}$ \\
\hline Wk-33535 & 5 & 2 & 6 & $-24.8 \pm 0.2$ & $157 \pm 25$ & $\begin{array}{c}284-244(16.6 \%) \\
230-166(38 \%) \\
155-131(10.6 \%) \\
118-68(11.7 \%) \\
36-(-) 3(18.5 \%) \\
\end{array}$ \\
\hline Wk-33533 & 13 & 2 & 26 & $-25.6 \pm 0.2$ & $241 \pm 25$ & $\begin{array}{c}422-407(1.9 \%) \\
317-272(58.8 \%) \\
184-150(28.9 \%) \\
10-(-) 4(5.9 \%) \\
\end{array}$ \\
\hline Wk-31821 & 21 & 2 & 43 & $-26.02 \pm 0.2$ & $1431 \pm 25$ & 1370-1295 (95.4\%) \\
\hline Wk-35590 & 28 & 2 & 56 & $-25.5 \pm 0.2$ & $1883 \pm 25$ & $\begin{array}{c}1860-1850(1.5 \%) \\
1826-1706(93.9 \%)\end{array}$ \\
\hline Wk-33534 & 33 & 2 & 68 & $-25.9 \pm 0.2$ & $237 \pm 25$ & $\begin{array}{c}418-414(0.5 \%) \\
315-270(55.4 \%) \\
186-150(32.2 \%) \\
12-(-) 4(7.4 \%) \\
\end{array}$ \\
\hline Wk-33536 & 39 & 2 & 85 & $-26.1 \pm 0.2$ & $1867 \pm 26$ & 1873-1726 (95.4\%) \\
\hline
\end{tabular}

Calibrations after OxCal 4.1 (Bronk Ramsay 2009). Ingaanjalwurr lies at the southern boundary of the Inter-tropical Convergence Zone (ITCZ), an area that may be influenced by northern hemisphere air masses (Hogg et al. 2013; Hua et al. 2012). For this reason the calibrations were performed with the IntCal 09 dataset of Reimer et al. (2009).

Source: Authors' data.

The colour of ochre pieces recovered from the excavations is consistent with the rock paintings at the site, consisting primarily of red, red-purple and red-yellow, with one unworked yellow piece recovered from XU19 in Square 2. Although white pigment is absent from the excavated assemblage, 18 per cent of paintings recorded at the site $(\mathrm{N}=14$ of 76 paintings) were either white $(\mathrm{N}=6)$ or contained white $(\mathrm{N}=8)$. Colour differentiation in the excavated red ochres, both worked and unworked, was in a comparable range as evident in the rock art, with 15 red, 15 red-purple and 13 red-yellow excavated pieces. 
There is a clear concentration of ochre, especially worked ochre, in the upper levels of both excavation squares. The uppermost 11 XUs of both squares contained all but two ( 85 per cent) of the worked ochre pieces. Taken at face value, this distribution indicates a concentration of ochre grinding after c. 300-460 cal BP, namely upward from XU11 in Square 1 and XU13 in Square 2. However, such an interpretation does not take into account preservation biases, such as increased rates of ochre disintegration with depth and through time.

Archaeological evidence for an earlier phase of ochre use is limited to one stone covered with red ochre, and a single piece of worked ochre, both from XU24 in Square 2. A radiocarbon date from XU21 indicates that XU24 is older than $1295-1370$ cal BP (Wk-31821). The decorated stone (size: $32.9 \times 21.8 \times 7.4 \mathrm{~mm}$; weight: $4.8 \mathrm{~g}$ ) is a fragment of an originally larger piece, possibly originating from the ceiling of the rockshelter. A major period of site use at this time is suggested by elevated rates of stone artefact discard and charcoal deposition.

In short, archaeological excavations at Ingaanjalwurr point to two primary periods of human activity: (a) an earlier phase from c. 1900 to c. 1300 cal BP; and (b) a later phase commencing c. 300-460 cal BP, which seemingly increases in intensity towards European contact. These two key periods of occupation at Ingaanjalwurr are separated by low-intensity site use. Although there is no guarantee that the excavated pieces of ochre relate to nearby on-wall paintings (see also McNiven et al. 2009), the chronostratigraphic integrity of excavated deposits and the congruence of peaks of worked ochre with those of stone artefacts suggest that the worked ochre is associated with pulses of occupation.

\section{Ethnographic evidence for activities at Ingaanjalwurr}

Discussions with Nakodjok and other Traditional Owners took place during June 2011 concerning past activities at Ingaanjalwurr. Over the past 100 years, the rockshelter has been used as a shortterm camp by people walking between Gunbalanya, Mudginberri, Pine Creek and other smaller settlements. Nakodjok was born in 1943 and recalled camping at the shelter in his youth 'for a day or two or maybe a week ... it was a good feeding ground for people those days ... looking for small breams and mussels' (Nakodjok, pers. comm. to Denis Shine 2011). Nakodjok stated that the camp was used during the dry season when the floodplains were drying out and bream could be easily caught with nets in retreating water pools around Ingaanjalwurr Creek.

None of Nakodjok's children remember camping at the site, suggesting that it had ceased to be used as a camping place by the 1960s, but they had occasionally visited the area to hunt rock wallaby (Petrogale spp.) since that time. Other Aboriginal Elders from Gunbalanya, including J. G. Namarnyilk (this senior Traditional Owner passed away in 2012; we refer to him by a shortened version of his name out of respect for his family's wishes) and Don Namundja, agreed that hunting was particularly rich around Ingaanjalwurr Creek. While not having specific knowledge of the site, they referred to the broader Ingaanjalwurr vicinity as an area that was regularly visited to hunt.

Nakodjok was interested in the high density of beeswax art present at Ingaanjalwurr. He understood that previous Traditional Owners of the area 'would invite other people to come and stay and that is why they did all those paintings'. He believed the density of beeswax art at the site resulted from 'somebody ... learning how to use the beeswax and paint'; 'when he learnt he'd do more better one ... somewhere else' (Nakodjok, pers. comm. 2011). Nakodjok also suggested that the concentration of beeswax art may simply reflect an availability of materials, as ochre is not easily available on the adjacent floodplains: 'because they had no colours you see a lot of wax painting there is no black or white, red, yellow ochre, all just wax, well you know they had plenty of wax to do the job'. 
Nakodjok believed the beeswax quadruped at Ingaanjalwurr depicts a horse. Horses were first introduced at early British fortified settlements such as Port Essington (AD 1838-1849) (Powell 1996). The image could also post-date AD 1845 , when Leichhardt visited the region on horseback; or possibly dates to the early 1900s when these animals were first introduced in large numbers by buffalo hunter Paddy Cahill (May 2006; May et al. 2010; Mulvaney 2004). Nakodjok had no recollection of people making beeswax art when he camped at the site, indicating that beeswax art was probably no longer being practised at Ingaanjalwurr in the mid-20th century.

\section{Discussion and conclusion}

We began this chapter by exploring the idea that in many rockshelters across western Arnhem Land, rock art was produced during bursts of activity (Taçon 1993:113) rather than gradually accumulating over prolonged periods of time as implied by Chaloupka's (1993) notion of 'longest continuing art tradition'. Accordingly, rock art at Ingaanjalwurr and elsewhere, as reported by Tacon (1993) and Gunn et al. (2012), was produced during relatively short periods of time associated with intense periods of occupation. Comparisons with the published data from Nawarla Gabarnmang to the south are of particular interest. Here Gunn et al. (2012:61) argued that a large quantity of art was produced within the past c. 350 years, while associated archaeological evidence suggests low-density occupation during the preceding 1000 years or so (David et al. 2011:76; Gunn et al. 2012:61; see Chapters 11 and 12). At Ingaanjalwurr, we found a period of beeswax art production dating to sometime after c. $275 \mathrm{cal} \mathrm{BP}$, either commencing in, or continuing into, the European-contact period (as indicated by the likely depiction of a horse). This period of heightened artistic activity coincides with a peak period of occupation commencing around c. 300-460 cal BP, as evidenced in the results of the archaeological excavations. There is also evidence for an earlier phase of activity at the site (including the use of red ochre) commencing within the calibration range 1726-1873 cal BP and continuing until c. 1295-1370 cal BP. However, the vast majority of the excavated red ochre fragments date to the later period of occupation, c. 300-460 cal BP. In short, the majority of surviving art at Ingaanjalwurr appears to have been produced during a short burst of activity incorporating the European-contact period.

If we accept that the past few hundred years witnessed increased human activity at the site, along with the appearance of beeswax and painted sorcery figures, then we must also question what cultural conventions inspired the making of such assemblages of art. Any such assessment requires consideration of the site within the transformational social contexts of the past 500 years, i.e. the period preceding and including European contact.

For at least the past 350 years, Aboriginal people in the East Alligator River region were in regular contact with Macassans (e.g. Macknight 1969, 1976, 1986; Taçon et al. 2010; Theden-Ringl et al. 2011) and, later, European explorers, hunters, settlers, police, World War II personnel and missionaries (i.e. Forrest 1985; Levitus 1995; Mulvaney 2004; Robinson 2005). Connections with more recent European settlement are suggested by the geographic positioning of Ingaanjalwurr rockshelter on an Aboriginal walking route linking Oenpelli with other settlements, such as the cattle station and Aboriginal encampment at Mudginberri (Levitus 1982; Esther Manakgu, pers. comm. to Sally K. May 2011). During the European-contact period, Aboriginal migration to, and between, European settlements was known to have been extensive in the East Alligator River region (Levitus 1995). Here, European contact resulted in a retraction of Aboriginal movements across the landscape, to direct routes between historic settlements such as the Oenpelli Mission (May et al. 2010). We suggest that Ingaanjalwurr was used intermittently, perhaps opportunistically, as Aboriginal people journeyed between these emerging settlements. 
The use of Ingaanjalwurr as a temporary camp on such journeys (as opposed to sustained occupation) is also reflected in the archaeological record for the site, with its relatively small number of artefacts but large volumes of charcoal and considerable number of rock art images, including contact period rock art. Likewise, the ethnographic information provided by Nakodjok specifically suggests that Ingaanjalwurr was a short-term camp for people moving along walking routes between settlements and utilising areas known for particular food resources.

There is also an interesting link between the earlier painted art of Ingaanjalwurr and the Europeancontact period. An important feature of this painted rock art is the presence of sorcery figures. Associations between rock art, sorcery and European illnesses across the region are well established (e.g. Chaloupka 1993; Taçon 1993). For the East Alligator River region, Chaloupka suggests that the majority of sorcery paintings date to the contact period and that they were probably a 'direct product of the stresses and sicknesses introduced by contact, such as the documented epidemics of influenza, measles, and leprosy which affected perhaps the majority of the population in the vicinity of Oenpelli' (Chaloupka 1983:15).

European diseases in the East Alligator River region, possibly deriving from contact with residents of or visitors to early British fortified settlements (Allen 2008), were recorded as early as the mid19th century (McKinlay 1866). However, both the incidence and array of European diseases increased massively following the foundation of Oenpelli and its development as an Anglican Mission Station after 1925 (e.g. see Barker 1978:12; Mulvaney 2004:53-55).

As Oenpelli grew, it became the primary source of European disease in the East Alligator River region (Taçon 1989:161-162) as well as, ironically, a place of pilgrimage and refuge for those seeking treatment. Sorcery figures are common in this area and are generally considered to be 'recent' in age, with none thought to be associated with art forms more than a few hundred years old (Chaloupka 1983:15; Taçon 1989:161).

The sorcery figures at Ingaanjalwurr are depicted with swollen/malformed joints. Taçon (1989:161) has previously contended that swollen joints were painted by Aboriginal people to document a symptom of Ross River fever, a type of mosquito-borne virus, which causes an influenza-like illness and polyarthritis (causing swelling and stiffness of joints). While Ross River fever was not officially named until the mid-20th century, Paddy Cahill documented serious outbreaks of a similar illness, which he classified as influenza, in 1917 and the early 1920s. The depiction of swollen joints on sorcery figures at Ingaanjalwurr, as at several other sites, could record Aboriginal perceptions of the disease that was at that time understood to be influenza. Alternatively, the disfigurement on these figures could relate to physical deformities caused by other diseases, such as leprosy and smallpox, which were also common in the East Alligator River region.

As noted above, some painted sorcery figures have been connected ethnographically to Namorrodoh, a malevolent magic man who Aboriginal people in the East Alligator River region associate with death and illness (e.g. Taçon 1989). Namorrodoh features heavily in Aboriginal narratives of the East Alligator River region, and have been documented from the Manilikarr and neighbouring Bunidj clans (see Shine et al. 2014). Among these clans, oral traditions pertaining to Namorrodoh have been recorded for Canon Hill, as well as for Owurrngarndt and Ubirr (e.g. Gunn 1992; Taçon 1989). Within the Manilikarr estate, Namorrodoh's image is depicted at Ubirr and Minjnyimirnjdawabu. Also located close to Minjnyimirnjdawabu, and contained within Red Lily Lagoon (Urrmarning) is Kungk, an Aboriginal sickness site, which was previously documented by Gunn (1992). Kungk, the Kunwinjku word for 'gut' or 'waist', is the only recorded sickness site within the Manilikarr estate and is associated with severe diarrhoea in local Aboriginal narratives (Gunn 1992:93). 
Ethnographic associations between beeswax art and sorcery, evil spirits and ritual activity have also been documented (Taçon et al. 1997, 2003:8). As mentioned above, Brandl (1968:28) suggested that some beeswax art could indicate increased ritual activity at a site. It has also been argued that by forming double rows of beeswax dots, or depicting the evil and dangerous spirit Narmarnde, it was possible to make a rockshelter habitable for the next season, presumably by ridding the shelter of these spirits (Chaloupka 1993:158; Taçon and Garde 2000:74). While this is, of course, just one level of interpretation, it does provide an interesting insight into the cultural complexity of this art form. Beeswax art has also been associated with the containment of deceased Ancestral spirits, the empowerment of body parts, and beliefs relating to the Rainbow Serpent (Chaloupka 1993:158; Chaloupka and Alderson 2000:24; Taçon et al. 2000). Each of these studies indicates that beeswax art can be imbued with a vital spiritual element, and that beeswax art is recalled ethnographically as being related to death, sickness and/or sorcery.

The concentration of sorcery figures at Ingaanjalwurr may be deliberate and part of a trend in the East Alligator River region, whereby Aboriginal people recorded the impact of European illnesses in both oral and visual (i.e. rock art) means. Thus we propose that much of the beeswax art and the painted sorcery figures may detail Aboriginal perceptions of a traumatic period in western Arnhem Land's history, a time that saw new introduced illnesses spreading quickly. The art thus arguably represents a form of social response to, and/or documentation of, a time of radical societal change.

\section{Acknowledgements}

We thank Nakodjok Nayinggul and his family for permission to undertake this research. We thank Stewart Fallon (The Australian National University) for radiocarbon dating, Injalak Arts (Gunbalanya) and the Northern Land Council for their ongoing support. Thanks to W. Nawirridj, Alfred Nayinggul, Gabriel Maralngurra, B. Nabegeyo, J.G. Namarnyilk, Don Namundja, Lionel Nayinggul, E. Manakgu, T. Yulidjirri, Lawrence Nayinggul and Garry Djorlom who have engaged with the project in many ways over the years. Special thanks to Andronicus Nayinggul for assisting in the excavation.

The excavations were funded by a Monash Research Accelerator grant awarded to Tim Denham, and ongoing analyses are partially funded by an Australian and Pacific Science Foundation grant awarded to Tim Denham and Denis Shine. Radiometric dating was provided by TD and Bruno David. Archaeological sorting was funded by the Student Summer Scholarship Scheme at Monash University. The PhD research of Denis Shine, including the excavations at Ingaanjalwurr, was supported by a Monash International Postgraduate Research Award Scholarship, Monash University Faculty of Arts Scholarship and internal support from the School of Geography and Environmental Science at Monash University. Finally, we thank the Place, Evolution and Rock Art Heritage Unit at Griffith University and the School of Archaeology and Anthropology at The Australian National University for supporting this research.

\section{References}

Allen, J. 2008. Port Essington: The Historical Archaeology of a North Australian Nineteenth-Century Military Outpost. University of Sydney Press, Sydney.

Barker, G.H. 1978. Alligator Rivers region - Historical Sketch to World War II. Australian Institute of Aboriginal Studies, Canberra.

Bednarik, R.G. 2001. The taphonomy of beeswax figures. Rock Art Research 18(2):91-95. 
Brandl, E.J. 1968. Aboriginal rock designs in beeswax and description of cave painting sites in Western Australia. Archaeology and Physical Anthropology in Oceania 3(1):19-29.

Brandl, E.J. 1973. Australian Aboriginal paintings in Western and Central Arnhem Land: Temporal Sequences and Elements of Style in Cadell River and Deaf Adder Creek Art. Australian Institute of Aboriginal Studies, Canberra.

Bronk Ramsey, C. 2009. Bayesian analysis of radiocarbon dates. Radiocarbon, 51(1):337-360. doi.org/ $10.1017 /$ S0033822200033865

Chaloupka, G. 1979. Pack-bells on the rock face: Aboriginal paintings of European contact in northwestern Arnhem Land. Aboriginal History 3(1):92-95.

Chaloupka, G. 1983. Kakadu rock art: Its cultural, historic and prehistoric significance. In D. Gillespie (ed), The Rock Art Sites of Kakadu National Park: Some Preliminary Research Findings for their Conservation and Management, pp. 3-33. Australian National Parks and Wildlife Service, Canberra.

Chaloupka, G. 1993. Journey in Time: The World's Longest Continuing Art Tradition. Reed, Chatswood.

Chaloupka, G. and M.C. Alderson 2000. Gunbirdi Bim: Beeswax art. In D.E. Nelson (ed.), The Beeswax Art of Northern Australia, pp. 17-28. Simon Fraser University, Burnaby.

David, B., J.-M. Geneste, R.L. Whear, J.-J. Delannoy, M. Katherine, R.G. Gunn, C. Clarkson, H. Plisson, P. Lee, F. Petchey, C. Rowe, B. Barker, L. Lamb, W. Miller, S. Hoerle', D. James, E. Boche, K. Aplin, I.J. McNiven, T. Richards, A. Fairbairn and J. Matthews 2011. Nawarla

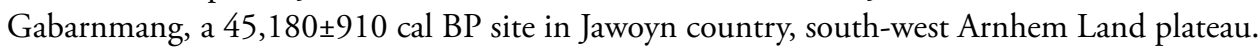
Australian Archaeology 73:73-77.

Forrest, P. 1985. An outline of the history of the Gunbalanya locality. Unpublished report for FACTS Pty Ltd, Darwin.

Gunn, R.G. 1992. Mikinj: Rock Art, Myth and Place. Unpublished report to Australian Institute of Aboriginal and Torres Strait Islander Studies, Canberra.

Gunn, R.G. and R.L. Whear 2008. A singular beeswax representation of Namarrkon, the Lightning Man, from western Arnhem Land. Australian Aboriginal Studies 2:54-69.

Gunn, R.G., R.L. Whear and L.C. Douglas 2012. Dating the present at Nawarla Gabarnmang: Time and function in the art of a major Jawoyn rock art and occupation site in western Arnhem Land. Australian Archaeology 75:55-65. doi.org/10.1080/03122417.2012.11681950

Hogg, A., Q. Hua, P. Blackwell, M. Niu, C. Buck, T. Guilderson, T.J. Heaton, J.G. Palmer, P.J. Reimer, R.W. Reimer, C.S.M. Turney and S. Zimmerman 2013. SHCAL13 Southern Hemisphere calibration, 0-50,000 years cal BP. Radiocarbon, 54(4):1889-1903. doi.org/10.2458/azu_js_ rc. 55.16783

Hua, Q., M. Barbetti, V. Levchenko, R. D’Arrigo, B. Buckley and A. Smith 2012. Monsoonal influence on Southern Hemisphere 14CO2. Geophysical Research Letters 39(19). doi.org/ 10.1029/2012GL052971

Levitus, R. 1982. 'Everybody bin all day work': A Report on the Social History of the Alligator Rivers Region of the Northern Territory 1869-1973. Unpublished report, Australian National Parks and Wildlife Service, Canberra.

Levitus, R. 1995. Social history since colonisation. In T. Press, D. Lea, A. Webb and A. Graham (eds), Kakadu Natural and Cultural Heritage and Management, pp. 64-93. Australian Nature Conservation Agency and the North Australian Research Unit, The Australian National University, Darwin. 
Macknight, C.C. 1969. The Macassans: A Study of the Early Trepang Industry along the Northern Territory Coast. Unpublished PhD thesis. The Australian National University, Canberra.

Macknight, C.C. 1976. The Voyage to Marege: Macassan Trepangers in Northern Australia. Melbourne University Press, Melbourne.

Macknight, C.C. 1986. Macassans and the Aboriginal past. Archaeology in Oceania 21(1):69-75. doi.org/10.1002/j.1834-4453.1986.tb00126.x

May, S.K. 2006. Karrikadjurren: Creating Community with an Art Centre in Indigenous Australia. Unpublished PhD thesis. The Australian National University, Canberra.

May, S.K. and P.S.C. Taçon. 2014. Kakadu National Park: Rock art. In C. Smith (ed.), Encyclopedia of Global Archaeology, pp. 4235-4240. Springer, New York. doi.org/10.1007/978-1-4419-0465-2_2241

May S.K, P.S.C. Taçon, D. Wesley and M. Travers 2010. Painting history: Indigenous observations and depictions of the 'Other' in north-western Arnhem Land, Australia. Australian Archaeology 71:57-65. doi.org/10.1080/03122417.2010.11689384

McKinlay, J. 1866. J. McKinlay's Northern Territory Explorations, 1866: Journal of Exploring Expedition. Ordered by the House of Assembly to be Printed, 2nd October, 1866. Government Printer, Adelaide.

McNiven, I.J., L.M. Brady and A.J. Barham 2009. Kabadul Kula and the antiquity of the Torres Strait rock art. Australian Archaeology 69:29-40. doi.org/10.1080/03122417.2009.11681899

Morwood, M.J., G.L. Walsh and A. Watchman 2010. AMS radiocarbon ages for beeswax and charcoal pigments in north Kimberley rock art. Rock Art Research 27:3-8.

Mountford, C.P. 1956. Records of the American-Australian Expedition to Arnhem Land 1948: Art, Myth and Symbolism. Melbourne University Press, Melbourne.

Mulvaney, D.J. 2004. Paddy Cahill of Oenpelli. Aboriginal Studies Press, Canberra.

Nelson, D.E. 2000. The Beeswax Art of Northern Australia. Simon Fraser University, Burnaby.

Nelson, D.E., G. Chaloupka, C. Chippindale, M.S. Alderson and J.R. Southon 1995. Radiocarbon dates for beeswax figures in the prehistoric rock art of northern Australia. Archaeometry 37(1):151-156. doi.org/10.1111/j.1475-4754.1995.tb00733.x

Nelson, D.E., C. Chippindale, G. Chaloupka and P.S.C. Taçon 2000. The plateau sites. In D.E. Nelson (ed.), The Beeswax Art of Northern Australia, pp. 67-82. Simon Fraser University, Burnaby.

Powell, A. 1996. Far Country: A Short History of the Northern Territory. Melbourne University Press, Melbourne.

Reimer, P.J., M.G. Baillie, E. Bard, A. Bayliss, J.W. Beck, P.G. Blackwell, C.B. Ramsey, C.E. Buck, G.S. Burr, R.L. Edwards and M. Friedrich 2009. IntCal09 and Marine09 radiocarbon age calibration curves, 0-50,000 years cal BP. Radiocarbon 51(04):1111-1150. doi.org/10.1017/ S0033822200034202

Robinson, C.J. 2005. Buffalo hunting and the feral frontier of Australia's Northern Territory. Social and Cultural Geography 6(6):885-901. doi.org/10.1080/14649360500353285

Shine, D. 2014. Changing Places: An Archaeological Study of Manilikarr Country in Western Arnhem Land. Unpublished PhD thesis, Monash University, Clayton. 
Shine, D., D. Wright, T. Denham, K. Aplin, P. Hiscock, K. Parker and R. Walton 2014. Birriwilk rockshelter: A mid- to late Holocene site in Manilikarr Country, southwest Arnhem Land, Northern Territory. Australian Archaeology 76:69-78. doi.org/10.1080/03122417.2013.11681967

Taçon, P.S.C. 1988. Identifying fish species in the recent rock paintings of western Arnhem Land. Rock Art Research 5(1):3-15.

Taçon, P.S.C. 1989. From Rainbow Snakes to 'X-Ray' Fish: The Nature of the Recent Painting Tradition in Western Arnhem Land. Unpublished PhD thesis. The Australia National University, Canberra.

Taçon, P.S.C. 1993. Regionalism in the recent rock art of western Arnhem Land, Northern Territory. Archaeology in Oceania 28(3):113-120. doi.org/10.1002/j.1834-4453.1993.tb00302.x

Taçon, P.S.C. and M. Garde 2000. Dating beeswax figures on rock: The view from central Arnhem Land. In G. Ward and C. Tuniz (eds), Advances in Dating Australian Rock-Markings: Papers from the First Australian Rock-picture Dating Workshop, pp. 71-75. Occasional AURA Publication 10. Australian Rock Art Research Association, Melbourne.

Taçon P.S.C., R. Fullagar, S. Ouzman and K. Mulvaney 1997. Cupule engravings from JinmiumGranilpi (northern Australia) and beyond: Exploration of a widespread and enigmatic class of rock markings. Antiquity 71(274):942-965. doi.org/10.1017/S0003598X00085847

Taçon, P.S.C., M. Garde, M. Kubarkku and B. Birriyabirriya 2000. Notes from central Arnhem Land. In D.E. Nelson (ed.), The Beeswax Art of Northern Australia, pp. 29-30. CD-ROM. Simon Fraser University, Burnaby.

Taçon, P.S.C., K. Mulvaney, S. Ouzman, R. Fullagar, P. Carlton and L. Head. 2003. Changing ecological concerns in the rock-art subject matter of north Australia's Keep River Region. Before Farming 2003/3(4):1-14. doi.org/10.3828/bfarm.2003.3.4

Taçon P.S.C., E.D. Nelson, C. Chippindale and G. Chaloupka 2004. The beeswax art of the Northern Territory: Direct dating results and a book of records. Rock Art Research 21(2):155-160.

Taçon, P.S.C., S.K. May, S. Fallon, M. Travers, D. Guse and R. Lamilami 2010. A minimum age for early depictions of Macassan praus in the rock art of Arnhem Land, Northern Territory. Australian Archaeology 71:1-10. doi.org/10.1080/03122417.2010.11689379

Taylor, L. 1996. Seeing the Inside: Bark Painting in Western Arnhem Land. Clarendon Press, Oxford.

Theden-Ringl, F., J.N. Fenner, D. Wesley and R. Lamilami. 2011. Buried on foreign shores: Isotope analysis of the origin of human remains recovered from a Macassan site in Arnhem Land. Australian Archaeology 73:41-48.

Walsh, G. 1988. Australia's Greatest Rock Art. E. J. Brill-Robert Brown and Associates, Sydney.

Watchman, A.L. and R. Jones 2002. An independent confirmation of the 4 ka antiquity of a beeswax figure in western Arnhem Land. Archaeometry 44(1):145-153. doi.org/10.1111/1475-4754.00049

Welch, D. 1995. Beeswax art in the Kimberley, Western Australia. Rock Art Research 12(1):23-28. 
This text is taken from The Archaeology of Rock Art in Western Arnhem Land, Australia, edited by Bruno David, Paul Taçon, Jean-Jacques Delannoy and Jean-Michel Geneste, published 2017 by ANU Press, The Australian National University, Canberra, Australia.

dx.doi.org/10.22459/TA47.11.2017.03 